\title{
CROSS-SPECIES APPLICABILITY OF MICROSATELLITE MARKERS FOR INVESTIGATION OF SEA DUCKS (Mergini) GENETIC DIFFERENTIATION
}

\author{
Aniolas Sruoga, Sigita Slavènaitè, Dalius Butkauskas, and Gediminas Gražulevičius \\ Institute of Ecology of Vilnius University, Akademijos 2, Vilnius, LITHUANIA \\ E-mail: aniolas@ekoi.lt
}

Communicated by İzaks Rašals

\begin{abstract}
Genetic studies of waterfowl have provided insufficient information on the evolutionary history of the sea duck tribe (Mergini, Anseriformes), as highly variable molecular markers have not been identified. Cross-species applicability of microsatellites has been shown for several bird families. Therefore, the objective of our work was to examine whether specific primers used previously for Anatidae, Phasianidae and Laridae taxons could amplify microsatellite loci of sea duck species: Long-tailed duck (Clangula hyemalis), Goosander (Mergus merganser) and Velvet Scoter (Melanitta fusca). Tissue samples were collected and DNA was extracted by rapid salt extraction method. Amplification of DNA fragments was carried out using specific microsatellite primers of APH21, Aalmu1, Sfimu4, Sfimu5 (Anatidae), ADL209, ADL115 (Phasianidae) and K71, RGB28 (Laridae). Four primer pairs (APH21, Aalmu1, K71, and nSfimu4) were suitable for investigation of interspecies genetic variability among Long-tailed duck and Velvet Scoter. Intraspecies specificity has been detected for primer pair ADL 209 in all three duck species. The primer pair APH21 was selected as most promising for investigation of intraspecies variability of Long-tailed duck and Velvet Scoter.
\end{abstract}

Key words: Anseriformes, sea ducks, microsatellites, genetic variability.

\section{INTRODUCTION}

The waterfowl of the order Anseriformes are an ecologically diverse group, which are the subject of extensive research and are intensively managed (Nichols et al., 1995). Genetic studies of waterfowl utilising allozyme electrophoresis and mitochondrial DNA have provided valuable information on their evolutionary history (Cooke and Buckley, 1987). However, highly variable molecular markers have not been identified for various taxons of this group.

Genetic markers vary greatly in evolutionary rates of change owing to heterogeneity, in modes of inheritance, sequence organisation, selective pressures, rates of mutation and fixation (Burke et al., 1992). Microsatellites are a class of markers that are used as powerful tool, for studying interand intrapopulation relationships (Hedrick, 1999). Of the genetic markers currently employed, microsatellites best fit the description of an ideal genetic marker because they have a large number of alleles, and therefore, a high likelihood of being polymorphic in any resource population. The detection of microsatellites is based on polymerase chain reaction, which requires small amounts of DNA, they are easily performed and reliably scored.
Many studies have shown that microsatellite loci are often conserved among closely related species including birds (Moore et al., 1991). Chicken microsatellite primers have been tested in another Galliformes, turkey (Meleagris gallopavo) (Levin et al., 1995; Liu et al., 1996). For example, markers developed for domestic species are potentially useful for even-hoofed mammals (Slate et al., 1998). The cross-species applicability of microsatellites in birds was also evaluated (Primmer et al., 1997). In waterfowl of the Anatidae family it has been established that 18 microsatellite markers of Peking duck (Anas platyrhynchos domesticus) amplify in Muscovy duck (Cairina moschata), Greylag goose (Anser anser), Swan goose (Anser cygnoides), and Canada goose (Branta canadensis) (Maak et al., 2003). The cross-species applicability of ten microsatellites of Common Eider (Somateria mollisima) was also shown for the Anatidae species: Bewick swan (Cygnus bewickii), Barnacle goose (Branta bernicla), Shelduck (Tadorna tadorna), Peking duck, Muscovy duck, Pochard (Aythya ferina), Velvet Scoter (Melanitta fusca) and Goosander (Mergus merganser) (Paulus and Tiedemann, 2003). Cross-species applicability is also likely among different species from the families Anatidae (Anseriformes) and Phasianidae (Galliformes). 
No specific microsatellite markers have yet been specifically developed for waterfowl of the sea duck (Mergini) tribe, excepting Stellers Eider (Polysticta stelleri) and Common Eider (Somateria mollisima)). This waterfowl tribe belongs to the well-delimited, presumably monophyletic family of Anatidae, with approximately 150 living species of ducks, geese and swans distributed world-wide. The family is generally divided into at least two major subfamilies: the Anserinae (tree ducks, geese and swans) and Anatinae (most other ducks) and a variable number of subfamilial tribes (Johnsgard, 1968; Bellrose, 1976; Sibbley and Alquist, 1990). While evidence from different methods of genetic data analysis shows the basal split between two subfamilies, there are ambiguities regarding phylogenetic relationships between subfamial tribes including sea ducks. The phylogenetic relationships of this tribe with diving ducks (Aythini) is not clear. Also the phylogenetic relationships of eiders with other sea duck tribe species need to be studied at the molecular level.

Due to wide use of microsatellites in phylogeny, inter and intrapopulation relationships, studies of the objective of our work was to examine, whether specific primer pairs for Anatidae, Phasianidae and Laridae taxons of birds can amplify microsatellite loci of sea duck tribe species: Longtailed duck (Clangula hyemalis), Goosander (Mergus merganser) and Velvet Scoter (Melanitta fusca) and to characterise polymorphic PCR products amplified.

\section{MATERIALS AND METHODS}

Tissue (heart) samples of birds were collected from sea duck tribe species: Long-tailed duck, Goosander and Velvet Scoter living near the Baltic Sea during winter and spring periods. Samples of DNA were extracted by using rapid salt extraction method (Aljanabi and Martinez, 1997). The fresh tissue was homogenised in $400 \mu \mathrm{l}$ sterile salt homogenizing buffer (0.4 M Nacl, $10 \mathrm{mM}$ Tris- $\mathrm{HCl}(\mathrm{pH} 8.0)$ and $2 \mathrm{mM}$ EDTA (pH 8.0)). $40 \mu \mathrm{l}$ of $20 \%$ SDS ( $2 \%$ final concentration) and $8 \mu \mathrm{l}$ of $20 \mathrm{mg} / \mathrm{ml}$ proteinase $\mathrm{K}(400 \mu \mathrm{g} / \mathrm{ml}$ final concentration) were added and mixed well. The samples were incubated at $55-65^{\circ} \mathrm{C}$ for $1 \mathrm{~h}$; then $300 \mu \mathrm{l} \mathrm{M} \mathrm{NaCl}$ was added to each sample. Samples were vortexed for $30 \mathrm{~s}$ at maximum speed and tubes spun down for $30 \mathrm{~min}$ at $10000 \mathrm{~g}$. The supernatant was transferred to fresh tubes. An equal volume of isopropanol was added to each sample, mixed well, and samples were incubated at $-20{ }^{\circ} \mathrm{C}$ for $1 \mathrm{~h}$. Samples were then centrifuged for $20 \mathrm{~min}, 4^{\circ} \mathrm{C}$ at $10000 \mathrm{~g}$. The pellet was washed with $70 \%$ ethanol, dried and finally resuspended in $300 \mu \mathrm{l}$ sterile $\mathrm{H}_{2} \mathrm{O}$. Amplification of DNA fragments was carried out by using specific microsatellite primers for various bird taxons in an Eppendorf Gradient Mastercycler (Eppendorf, Germany). Data for primers are shown in Tables 1 and 2. The final volume of polymerase chain reaction consisted of $25 \mu \mathrm{l}$. Reactions were initially denatured for $3 \mathrm{~min}$ at $94{ }^{\circ} \mathrm{C}$, then 30 cycles of $94{ }^{\circ} \mathrm{C}$ for $1 \mathrm{~min}, 43$ to 58 for $1 \mathrm{~min}$ and $72{ }^{\circ} \mathrm{C}$ for $1 \mathrm{~min}$, with a final elongation step at $72{ }^{\circ} \mathrm{C}$. Samples of amplification products

Table 1

CHARACTERISTICS OF SPECIES-SPECIFIC MICROSATELITE PRIMER PAIRS OF VARIOUS BIRD TAXONS

\begin{tabular}{|c|c|c|c|c|}
\hline Taxon & Locus & Motif & Size (bp) & GenBank Accession number \\
\hline $\begin{array}{l}\text { Anatidae } \\
\text { Anas acuta } \\
\text { Anser albifrons } \\
\text { Branta bernicla } \\
\text { Polysticta stelleri } \\
\text { Cygnus columbianus }\end{array}$ & Sfimu4 & $(\mathrm{GA})_{13}$ & 163 & U63685 \\
\hline $\begin{array}{l}\text { Anatidae } \\
\text { Anas acuta } \\
\text { Anser albifrons } \\
\text { Branta bernicla } \\
\text { Polysticta stelleri } \\
\text { Cygnus columbianus }\end{array}$ & Sfimu5 & $(\mathrm{GA})_{10} \mathrm{~N}_{5}(\mathrm{GA})_{6} \mathrm{~N}_{16}(\mathrm{GA})$ & 156 & U63686 \\
\hline $\begin{array}{l}\text { Anatidae } \\
\text { Anas platyrhynchos }\end{array}$ & APH21 & $(\mathrm{CA})_{8}$ & 137 & AJ515896 \\
\hline $\begin{array}{l}\text { Anatidae } \\
\text { Aythya marila } \\
\text { Anas acuta } \\
\text { Anser albifrons } \\
\text { Branta bernicla } \\
\text { Polysticta stelleri } \\
\text { Cygnus columbianus }\end{array}$ & Aalmu1 & $(\mathrm{CA})_{15}$ & 85 & U63689 \\
\hline \multicolumn{5}{|l|}{ Phasianidae } \\
\hline Gallus gallus & ADL 115 & $(\mathrm{TA})_{8}(\mathrm{GTT})_{9}$ & $\begin{array}{l}109 \\
163\end{array}$ & $\begin{array}{l}\text { G0 } 1556 \\
\text { G0 } 1629\end{array}$ \\
\hline Laridae & & & & AY083602 \\
\hline Rissa tridactyla & K71 & $(\mathrm{AC})_{11}$ & $147-153$ & AY091850 \\
\hline Larus novaehollandiae & RGB28 & $(\mathrm{AC})_{3} \mathrm{AT}(\mathrm{AC})_{11} \mathrm{AT}(\mathrm{AC})_{6}$ & $174-210$ & \\
\hline
\end{tabular}


SEQUENCES OF SPECIES-SPECIFIC MICROSATELLITE PRIMER PAIRS FOR ANATIDAE, PHASIANIDAE, LARIDAE BIRD TAXONS

\begin{tabular}{|l|l|}
\hline ADL 209 & F: GGT TAG CTC CCTCCTTCCAG \\
& R: TCACTCCAGCTTGAGACAGG \\
ADL 115 & F: GGATGAGAAGAAGAAAGGCA \\
& R: CAATGGTGGTTCAGGTAATC \\
APH21 & F: CTTAAAGCAAAGCGCACGTC \\
& R: AGATGCCCAAAGTCTGTGCT \\
Sfimu4 & F: CTGAGGGGGAAGAGAATAAGAGA \\
& R: CAGGGCAGTATTTTCAGGACATT \\
Sfimu5 & F: TTCATTCAAAATAAGACAAGA \\
Aalmu1 & R: ATTTTGCTCTGTTTGGTTTA \\
& F: CATGCTGTTTAAGGGGTAT \\
K71 & R: TAAGACTTGCGTGAGGAATA \\
& F: TAGTCTGGAGGATTGCAAATG \\
RGB28 & R: AAACAACACCAAGAGGAAGG \\
& F: ACAAACTTCTGGTGCCCC \\
R: TACACACCCCATTGCATTTC
\end{tabular}

$(15 \mu \mathrm{l})$ were dissolved electrophoretically on $12 \%$ polyacrilamide gels by using tris EDTA - borate buffer and then stained in $0.5 \mu \mathrm{g} / \mathrm{ml}$ ethidium bromide. The electrophoresis was performed with constant voltage at $200 \mathrm{~V}$ for 3 to 4 hours. The PCR products were visualised in an UV transilluminator, photographed and evaluated.

\section{RESULTS}

The number of amplified DNA fragments detected with microsatellite markers of various bird taxons is presented in Table 3. The amplification was successful with all primer pairs in Long-tailed duck. In the other two species PCR products were not obtained with Sfimu5 and RGB28 in Velvet Scoter and with all primer pairs except chicken specific primer pairs (ADL 209) in Goosander. The highest number of DNA fragments was detected with primer pair APH21, ranging from 10 to13 bands in Long-tailed duck and from 7-12 bands in Velvet Scoter. The size of PCR products differed for the species: shortest DNA fragments in Goosander (50-100) bp and the longest in Velvet Scoter (50-320) bp. Since the non-specific primers indicated that homozygous and heterozygous individuals of sea ducks tribe species possessed different amounts of alleles, the primers were suggested as useful tools for further investigation of intraspecies and interspecies genetic variability among three sea ducks tribe species. Seven (Sfimu4, Sfimu5, ADL209, APH21, RGB28, Aalmu1, K71) microsatellite primer pairs were considered suitable for investigation of intraspecies genetic variability in Long-tailed duck, five (Sfimu4, ADL209, APH21, Aalmu1, K71) in Velvet Scoter and one (ADL209) in Goosander. Four primer pairs (APH21, Aalmu1, K71, and Sfimu4) were found suitable for investigation of interspecies genetic variability among Long-tailed duck and Velvet Scoter. The amplification products obtained with the ADL115 primer pair had the same size in all species investigated, therefore, this primer pair was not suitable for further investigation of genetic variability among the three sea duck tribe species. Low intraspecies specificity
NUMBER AND SIZE OF AMPLIFIED DNA FRAGMENTS IN VARIOUS SPECIES OF THE SEA DUCK (MERGINI) TRIBE

\begin{tabular}{|c|c|c|c|}
\hline $\begin{array}{l}\text { Genomic } \\
\text { markers }\end{array}$ & Taxon & $\begin{array}{c}\text { Number of DNA } \\
\text { fragments }\end{array} \mid$ & $\begin{array}{c}\text { Length of DNA } \\
\text { fragments }\end{array}$ \\
\hline \multirow[t]{3}{*}{ ADL 115} & Clangula hyemalis & 2 & $60-80$ \\
\hline & Melanitta fusca & 2 & $60-80$ \\
\hline & Mergus merganser & 2 & $60-80$ \\
\hline \multirow[t]{3}{*}{ ADL209 } & Clangula hyemalis & $1-2$ & $50-75$ \\
\hline & Melanitta fusca & $1-2$ & $50-75$ \\
\hline & Mergus merganser & $1-2$ & $50-100$ \\
\hline \multirow[t]{3}{*}{ APH21 } & Clangula hyemalis & $10-13$ & $50-350$ \\
\hline & Melanitta fusca & $7-12$ & $50-320$ \\
\hline & Mergus merganser & - & - \\
\hline \multirow[t]{3}{*}{ Sfimu4 } & Clangula hyemalis & $3-6$ & $160-450$ \\
\hline & Melanitta fusca & $7-12$ & $50-320$ \\
\hline & Mergus merganser & - & - \\
\hline \multirow[t]{3}{*}{ Sfimu5 } & Clangula hyemalis & $3-7$ & $60-300$ \\
\hline & Melanitta fusca & - & - \\
\hline & Mergus merganser & - & - \\
\hline \multirow[t]{3}{*}{ Aalmu1 } & Clangula hyemalis & $4-6$ & $75-250$ \\
\hline & Melanitta fusca & $7-14$ & $75-450$ \\
\hline & Mergus merganser & - & - \\
\hline \multirow[t]{3}{*}{ K71 } & Clangula hyemalis & $6-10$ & $75-300$ \\
\hline & Melanitta fusca & $6-12$ & $80-310$ \\
\hline & Mergus merganser & - & - \\
\hline \multirow[t]{3}{*}{ RGB28 } & Clangula hyemalis & $6-10$ & $50-400$ \\
\hline & Melanitta fusca & - & - \\
\hline & Mergus merganser & - & - \\
\hline
\end{tabular}

was observed for the primer pair ADL 209 in all three sea duck species investigated.

\section{DISCUSSION}

The sea duck tribe is thought to be well delineated, showing no close relations with other tribes (Delacour and Mayr, 1945). However, investigations based on protein electrophoresis show that two species of sea ducks Goldeney (Bucephala clangula) and Bufflehead (Bucephala albeola) appears genetically close to pochard (Aythini). Also three genera of sea ducks (Bucephala, Clangula, Melanitta) exhibit no particular ties to each other (Patton and Avise, 1986). Other traditional classifications had considered the pochards to be closely related in a subfamily Aythyinae (Robbins et al., 1966). In early investigations eiders were separated from the other sea ducks (Humphrey, 1955; Cramp and Simmons, 1977). A clear distinction between eiders and other species of sea ducks was found using feather proteins (Brush, 1976).

The composition of integument lipids confirmed moderate distance between Common eider and several other genera of sea ducks (Jacob and Glaser, 1975). The electrophoresis of 13 proteins showed a moderately large distance between two species of Bucephala genus and the two other sea duck 
genera (Melanitta and Clangula) (Patton and Avise, 1986). A recent comparison of Anseriformes using DNA hybridisation includes only a single representative of sea ducks (Melanitta), and therefore, provides no insight into relationships within the tribe (Sibbley and Alquist, 1990; Sibbley and Monroe, 1990). Similarly, comparisons using the same method included only one species of sea duck, Hooded Merganser (Lophodytes cucullatus) (Madsen et al., 1988).

The cross-species applicability of APH21, Sfimu4, Sfimu5, Aalmu1, K71, RGB28, and ADL209 markers for investigation of interspecies and intraspecies variety allows their use in increasing knowledge of sea duck evolutionary history.

\section{REFERENCES}

Aljanabi, S.M., Martinez, I. (1997). Universal and rapid salt-extraction of high quality genomic DNA for PCR based techniques. Nucl. Acids Res., 25(22), 4692-4693.

Bellrose, F.C. (1976). Ducks, Geese and Swans of North America. Harrison: Stackpole Books. 540 pp.

Brush, A.H., (1976). Waterfowl feather proteins: Analysis of use in taxonomic studies. J. Zool. London, 179, 467-498.

Burke, T., Rainey, W.E., White, T.J. (1992). 33rd Symposium of the British Ecological Society. In Genes in Ecology (pp. 229-254). Berry, R.J., Crawford, T.J., Hewitt, G.M. (eds.). Oxford: Blackwell Scientific Publications.

Cooke, F., Buckley, P.A. (1987). Avian Genetics: A Population and Ecological Approach. New York: Academic Press. 488 pp.

Cramp, S., Simmons, K.E.L. (1977). Handbook of the Birds of Europe and the Middle East and North Africa. Vol. 1. Oxford: Oxford Univ. Press. $722 \mathrm{pp}$.

Delacour, J., Mayr, E. (1945). The family Anatidae. Wilson Bull., 57, 3-55.

Hedrick, P.W. (1999). Perspective: Highly variable loci and their interpretation in evolution and conservation. Evolution, 53, 313-318.

Humphrey, P.S. (1955). The relationships of the sea ducks (tribe Mergini). Ph.D. diss., Univ of Michigan, Ann Arbor.

Jacob, J., Glaser A. (1975). Chemotaxonomy of Anseriformes. Biochem. Systemat. Ecol., 2, 215-220.
Johnsgard, P.A. (1968). Waterfowl. Lincoln, Nebraska: University Nebraska Press. 168 pp.

Levin, I., Cheng, H.H., Baxter-Jones, C., Hillel J. (1995). Turkey microsatellite DNA loci amplified by chicken-specific primers. Animal Gen., 26, 107-110.

Liu, Z., Crooijmans, R.P.M.A., van der Poel, J.J., Groenen, M.A.M. (1996). Use of chicken microsatellite markers in turkey: A pessimistic view. Animal Gen., 27, 191-193.

Maak, S., Wimmers, K., Weigend, S., Neumanns, K. (2003). Isolation and characterization of 18 microsatellites in the Peking duck (Anas platyrhynchos) and their application in other waterfowl species. Mol. Ecol. Notes, 3, 224-227.

Madsen, C.S., McHugh, K.P., Kloet, S.R. (1988). A partial classification of waterfowl (Anatidae) based on single copy DNA. Auk, 105, 452-459.

Moore, S.S., Sargeant, L.L., King T.J. (1991). The conservation of dinucleotide microsatellites among mammalian genomes allows the use of heterologous PCR primer pairs in closely related species. Genomics, 10, 654-660.

Nichols, J.D., Johnson, F.A., Williams, B.K. (1995). Managing North American waterfowl in the face of uncertainty. Annu. Rev. Ecol. Systemat., 26, 177-199.

Patton, J.C., Avise, J.C. (1986). Evolutionary genetics of birds IV: Rates of protein divergence in waterfowl (Anatidae). Genetica, 68, 129-143.

Paulus, K.B., Tiedemann, R. (2003). Ten polymorphic autosomal microsatellite loci for the Eider duck Somateria mollisima and their cross-species applicability among waterfowl species (Anatidae). Mol. Ecol. Notes, 3, 250-252.

Primmer, C.R., Raudsepp T., Chowdhary, B.P., Moller, A.P., Ellegren, H. (1997). Low frequency of microsatellites in the avian genome. Genome Res., 7(5), 471-482.

Robbins, C.S., Bruun, B., Zim, H.S. (1966). Birds of North America. New York: Golden press. $340 \mathrm{pp}$.

Slate, J., Coltman, D.W., Goodman S.J., MacLean, I., Pemberton, J.M., Williams, J.L. (1998). Bovine microsatellite loci are higly conserved in red deer (Cervus elaphus), sika deer (Cervus nippon) and Soay sheep (Ovis aries). Animal Gen., 29(4), 307-315.

Sibley, C.G., Ahlquist, J.E. (1990). Phylogeny and Classification of Birds: A Study in Molecular Evolution. New Haven: Yale University Press. $1008 \mathrm{pp}$.

Sibley, C.G., Monroe, B.L. (1990). Distribution and Taxonomy of Birds of the World. New Haven: Yale University Press, 1111 pp.

Received 17 October 2007

\section{MIKROSATELĪTU MARĶIERU STARPSUGU PIELIETOJAMĪBA JŪRAS PĪḶU (Mergini) ĢENĒTISKO ATŠKIRĪBU PĒTĪJUMOS}

Pētījumu mērkis bija noteikt, vai specifiskie praimeri, kuri ir izstrādāti Anatidae, Phasianidae un Laridae taksoniem, var amplificēt mikrosatelītu lokusus jūras pị̄ sugām Clangula hyemalis, Mergus merganser un Melanitta fusca. Atrasti praimeri, kuri ir vispiemērotākie starpsugu ğenētiskās daudzveidības analīzei. 